\title{
Effects of Zinc Coadministration on Lead Toxicities in Rats
}

\author{
Fengyuan PIAO ${ }^{1 *}$, Fanyin $\mathrm{CHENG}^{2}$, Haibo CHEN ${ }^{3}$, Gang $\mathrm{LI}^{4}$, Xiance SUN${ }^{1}$, \\ Shuang LIU ${ }^{1}$, Toru YAMAUCHI ${ }^{5}$ and Kazuhito YOKOYAMA ${ }^{5}$
}

\author{
${ }^{1}$ Department of Hygiene, Dalian Medical University \\ ${ }^{2}$ Department of Health Administration, Dalian Medical University \\ ${ }^{3}$ Central laboratory, Dalian Medical University, Zhongshan Road, Dalian 116027, P.R. China \\ ${ }^{4}$ Liaoning Institute of Occupational Health, Shenyang 110005, P.R. China \\ ${ }^{5}$ Department of Public Health, Graduate School of Medicine, Mie University, 2-174 Edobashi, Tsu, Mie \\ 514-8507, Japan
}

Received January 12, 2007 and accepted May 22, 2007

\begin{abstract}
In order to investigate the effects of $\mathrm{Zn}$ on Pb toxicities. Proportion of abnormal sperm, percentage of micronucleated polychromatic erythrocyte (MPCE), serum thyroid hormones $\left(\mathbf{T}_{3}, \mathbf{T}_{4}\right)$ and cortisol were measured. Rats received intraperitoneal injection of $25 \mathrm{mg} / \mathrm{kg} \mathrm{Pb}$ acetate, $4 \mathrm{mg} / \mathrm{kg}$ $\mathrm{Zn}$ acetate, both $\mathrm{Pb}$ acetate and $\mathrm{Zn}$ acetate, or normal saline as controls, once every two days, 7 times in total. No significant differences in whole blood $\mathrm{Pb}$ were detected between groups received $\mathrm{Pb}$ alone or both $\mathrm{Pb}$ and $\mathrm{Zn}$. On the contrary, the concentration of whole blood $\mathrm{Zn}$ in the group given $\mathrm{Zn}$ alone was significantly higher than that in the group that received both $\mathrm{Pb}$ and $\mathrm{Zn}$. In the groups given $\mathrm{Pb}$ alone or both $\mathrm{Pb}$ and $\mathrm{Zn}$, proportion of abnormal sperm, frequency of MPCE and serum cortisol were significantly higher than those in controls, whereas serum $T_{3}$ and $T_{4}$ were significantly lower than in controls. In the group given both $\mathrm{Pb}$ and $\mathrm{Zn}, \mathrm{T}_{4}$ was decreased most obviously among the four groups. While the proportion of abnormal sperm was less in the group given both $\mathrm{Pb}$ and $\mathrm{Zn}$ than in the group given $\mathrm{Pb}$ alone. These findings suggest that $\mathrm{Zn}$ coadministration might alleviate toxic effects of $\mathrm{Pb}$ on the male reproductive system, whereas it could enhance the toxicity on thyroid function. $\mathrm{Zn}$ did not affect the toxicities of $\mathrm{Pb}$ on cytogenetic systems as indicated by MPCE percentage, and on serum cortisol levels under the dose of the present study. Our results suggested the double-edged effects of $\mathrm{Zn}$ on $\mathrm{Pb}$ toxicities in different organs. Therefore, the effects of $\mathrm{Zn}$ on $\mathrm{Pb}$ toxicities should be evaluated systematically.
\end{abstract}

Key words: Lead acetate, Zinc acetate, Male reproductive system, Cytogenetics, Endocrine system

\section{Introduction}

Since the recognition of zinc ( $\mathrm{Zn})$ as an essential nutrient, many researchers have studied its role in the prevention and treatment of toxic metals such as lead $(\mathrm{Pb})$, cadmium and mercury, as well as organic solvents such as ethanol and carbon tetrachloride ${ }^{1-\sigma)}$. In particular, these studies have mainly focused on the protective effects of $\mathrm{Zn}$ on $\mathrm{Pb}$ toxicities.

\footnotetext{
*To whom correspondence should be addressed.
}

Cerklewski and Forbes ${ }^{2)}$ reported that as dietary Zn increased, severity of $\mathrm{Pb}$ toxicity decreased, including decreases of $\mathrm{Pb}$ concentration in the blood, liver and kidneys, excretion of urinary delta-aminolevulinic acid, and inhibition of kidney delta-aminolevulinic acid dehydratase (ALAD) activity in rats. Hasan and $\mathrm{Seth}^{7)}$ reported that erythrocytic ALAD activity was significantly decreased by $\mathrm{Pb}$ but not by a combination of $\mathrm{Pb}$ and $\mathrm{Zn}$. Flora et al ${ }^{8}{ }^{8}$ demonstrated that $\mathrm{Zn}$ administration together with $\mathrm{Pb}$ decreased hepatic and renal uptake of $\mathrm{Pb}$ and reduced $\mathrm{Pb}$-induced inhibition of 
blood ALAD activity. In addition, Batra et al. ${ }^{9)}$ reported that testicular degeneration was observed in rats exposed to high doses of $\mathrm{Pb}$ and that, with a concomitant administration of $\mathrm{Pb}$ and $\mathrm{Zn}$, both testes and epididymides presented nearly normal pictures. However, these experimental studies mainly involved in the protective effects of $\mathrm{Zn}$ against $\mathrm{Pb}$ toxicity to the hematopoietic and male reproductive systems, and there are few reports on the interactions of $\mathrm{Zn}$ in $\mathrm{Pb}$ toxicities to other organs.

To further explore the interactions of $\mathrm{Zn}$ on $\mathrm{Pb}$ toxicities to male reproductive system, cytogenetics, thyroid and adrenal cortex, the present study was designed to examine the proportion of abnormal sperm, percentage of micronucleated polychromatic erythrocyte, serum thyroid hormones $\left(\mathrm{T}_{3}, \mathrm{~T}_{4}\right)$ and cortisol in rats administered $\mathrm{Pb}, \mathrm{Zn}$, or both.

\section{Materials and Methods}

\section{Chemicals}

$\mathrm{Pb}$ acetate (purity: $99.6 \%$ ) and $\mathrm{Zn}$ acetate (purity: $98.9 \%$ ) were purchased from Wako Pure Chemical Industries (Osaka, Japan). Nitric acid, hydrogen peroxide and the other chemicals were obtained from Shenyang Chemical Industries (Shenyang, China).

\section{Animals and treatment}

Fifty-six Wistar rats weighing 160-190 g were purchased from the animal center of China Medical University and were caged under a 12-h dark-light cycle. The animals were acclimatized to their new environment for $1 \mathrm{wk}$ before the initiation of treatment. The rats were randomly segregated into four groups ( 7 males and 7 females in each group). In order to induce obvious toxic effects of $\mathrm{Pb}$, a dose of $25 \mathrm{mg} /$ $\mathrm{kg}$ was selected according to literatures ${ }^{9-11}$. $\mathrm{Pb}$ acetate or $\mathrm{Zn}$ acetate was dissolved in sterile double distilled water (DDW). Rats received intraperitoneal injection of $25 \mathrm{mg} / \mathrm{kg} \mathrm{Pb}$ acetate ( $\mathrm{Pb}$ group), $4 \mathrm{mg} / \mathrm{kg} \mathrm{Zn}$ acetate ( $\mathrm{Zn}$ group) ${ }^{12-14)}$, both $\mathrm{Pb}$ acetate and $\mathrm{Zn}$ acetate $(\mathrm{Pb}+\mathrm{Zn}$ group) or DDW (controls), once every two days, 7 times in total. Approximately $2.6 \mathrm{ml}$ of blood was collected from the heart of each rat for analyses of whole blood $\mathrm{Pb}$, whole blood $\mathrm{Zn}$, serum thyroid hormones and cortisol after the last administration, and then all rats were undergone necropsy. Seven rats were used for analyses of micronucleated polychromatic erythrocytes (MPCE). Testes and epididymides dissected from all seven males in each group, and the proportion of abnormal sperm was assessed. Animal experiment was conducted in accordance with the Guiding Principles in the Use of Animals in Toxicology, which was adopted by the Chinese Society of Toxicology.

\section{Whole Blood $\mathrm{Pb}(\mathrm{BPb})$ and $\mathrm{Zn}(\mathrm{BZn})$ analyses}

Blood samples $(0.5 \mathrm{ml})$ were digested with nitric acid and $3 \%$ of hydrogen peroxide. Concentrations of $\mathrm{Pb}(283.3$ $\mathrm{nm})$ and $\mathrm{Zn}(307.6 \mathrm{~nm})$ were measured on an atomic absorption spectrophotometer (Varian AA-40) using appropriate standards of the two metals. Duplicate tests were carried out for each sample. Quality control was performed by determination of the reference samples from the Institute of Environmental Monitoring, Chinese Academy of Preventive Medicine (Calf blood serum GBW091039 and Calf blood GBW09131 as the reference for determination of $\mathrm{Pb}$ and $\mathrm{Zn}$, respectively). The reference values $(\mathrm{Pb}: 109$ $\pm 23 \mu \mathrm{g} / \mathrm{l} ; \mathrm{Zn}: 698 \pm 0.2 \mu \mathrm{g} / \mathrm{l})$ measured by the present laboratory were almost the same as the authentic standard $(\mathrm{Pb}: 110 \pm 20 \mu \mathrm{g} / \mathrm{l} ; \mathrm{Zn}: 710 \pm 0.1 \mu \mathrm{g} / \mathrm{l})$. The accuracy of this method was checked by the analytical recoveries of added $\mathrm{Pb}$ or $\mathrm{Zn}$, and found to be satisfactory. The blood $\mathrm{Pb}$ recoveries $(\mathrm{M} \pm \mathrm{SD})$ were $106 \pm 8 \%(\mathrm{RSD}=1.61 \%)$ and $105 \pm 8 \%(\mathrm{RSD}=3.7 \%)$ when the concentrations of standard $\mathrm{Pb}$ solution were $50 \mu \mathrm{g} / \mathrm{l}$ and $100 \mu \mathrm{g} / \mathrm{l}$, respectively. Detection limit of $\mathrm{Pb}$ was $1.78 \mu \mathrm{g} / \mathrm{l}$. The blood $\mathrm{Zn}$ recoveries $(\mathrm{M} \pm$ $\mathrm{SD})$ were $98 \pm 8 \%(\mathrm{RSD}=2.35 \%)$ and $99 \pm 8 \%(\mathrm{RSD}=$ $1.89 \%$ ) when the concentrations of standard $\mathrm{Zn}$ solution were $50 \mu \mathrm{g} / \mathrm{l}$ and $100 \mu \mathrm{g} / \mathrm{l}$, respectively. Detection limit of $\mathrm{Zn}$ was $1.8 \mu \mathrm{g} / 1^{15,16)}$.

\section{Abnormal sperm examination}

The epididymides of 7 male rats were removed within 2 min of death, finely minced, and immediately placed in 3 ml Tyrode's solution $[0.8 \mathrm{~g} \mathrm{NaCl}, 0.02 \mathrm{~g} \mathrm{KCl}, 0.02 \mathrm{~g} \mathrm{CaCl}$ (anhydrous), $0.01 \mathrm{~g} \mathrm{MgCl}_{2}$ (anhydrous), $0.005 \mathrm{~g} \mathrm{NaH}_{2} \mathrm{PO}_{4}$ (anhydrous) and $0.01 \mathrm{~g}$ glucose; volume adjusted to $100 \mathrm{ml}$ with distilled water] at $37^{\circ} \mathrm{C}$ for 20 min to ensure an even distribution of sperm ${ }^{17}$. The suspension was filtered through a nylon mesh. To examine the sperm morphology, a drop of the sperm suspension was placed on a glass slide, the smear was fixed in ethanol for $1 \mathrm{~h}$, stained with Giemasa stain for 15-20 min, washed, dried, and examined with a light microscope at $100 \times$ magnification. One thousand sperms were counted and the percentage of abnormal sperm was determined. Morphologic abnormalities included enlarged, undersized, deformed, or double-headed sperm and sperms with coiled, short, or double tails ${ }^{17}$.

\section{Percentage of micronucleated polychromatic erythrocytes (MPCE)}

Sterna were dissected from the sacrificed rats and bone 
Table 1. Concentrations of whole blood lead (BPb) and zinc (BZn) in four groups of rats

\begin{tabular}{|c|c|c|c|c|}
\hline \multirow[t]{2}{*}{ Groups } & \multicolumn{2}{|c|}{ Treatment $(\mathrm{mg} / \mathrm{kg})$} & \multirow{2}{*}{$\begin{array}{c}\mathrm{BPb} \\
(\text { mean } \pm \mathrm{SD}) \mu \mathrm{g} / \mathrm{l}\end{array}$} & \multirow{2}{*}{$\begin{array}{c}\mathrm{BZn} \\
(\text { mean } \pm \mathrm{SD}) \mu \mathrm{g} / \mathrm{l}\end{array}$} \\
\hline & $\mathrm{Pb}$ acetate & $\mathrm{Zn}$ acetate & & \\
\hline Controls & 0 & 0 & $18 \pm 8$ & $690 \pm 225$ \\
\hline $\mathrm{Zn}$ & 0 & 4 & $15 \pm 2$ & $728 \pm 162$ \\
\hline $\mathrm{Pb}$ & 25 & 0 & $67 \pm 28^{\mathrm{a}, \mathrm{c}}$ & $643 \pm 217$ \\
\hline $\mathrm{Pb}+\mathrm{Zn}$ & 25 & 4 & $71 \pm 36^{\mathrm{a}, \mathrm{c}}$ & $571 \pm 125^{b}$ \\
\hline
\end{tabular}

${ }^{\mathrm{a}} p<0.01$, compared with control group; ${ }^{\mathrm{b}} p<0.05$ and ${ }^{\mathrm{c}} p<0.01$ compared with Zn group. Statistical analysis was conducted using the Scheffe's test.

Table 2. Effect of $\mathrm{Zn}$ on the MPCE

\begin{tabular}{|c|c|c|c|c|c|}
\hline \multirow[t]{2}{*}{ Groups } & \multicolumn{2}{|c|}{ Treatment $(\mathrm{mg} / \mathrm{kg})$} & \multirow{2}{*}{$\begin{array}{l}\text { No. of } \\
\text { PCEs }^{\mathrm{a}}\end{array}$} & \multirow{2}{*}{$\begin{array}{c}\text { No. of } \\
\text { MPCEs }^{\mathrm{b}}\end{array}$} & \multirow{2}{*}{$\frac{\text { Percentage }}{(\%)}$} \\
\hline & $\mathrm{Pb}$ acetate & $\mathrm{Zn}$ acetate & & & \\
\hline Controls & 0 & 0 & 7,000 & 23 & 0.33 \\
\hline $\mathrm{Zn}$ & 0 & 4 & 7,000 & 25 & 0.35 \\
\hline $\mathrm{Pb}$ & 25 & 0 & 7,000 & 40 & $0.57^{\mathrm{c}}$ \\
\hline $\mathrm{Pb}+\mathrm{Zn}$ & 25 & 4 & 7,000 & 44 & $0.63^{\mathrm{c}}$ \\
\hline
\end{tabular}

aPCEs: Polychromatic erythrocytes; ' ${ }^{\mathrm{M}} \mathrm{MCEs}$ : Micronucleated polychromatic erythrocytes; ${ }^{\mathrm{c}} p<0.05$, compared with control group by the $\chi^{2}$ test.

marrow was flushed out with $0.5 \mathrm{ml}$ of bovine serum albumin into a $10 \mathrm{ml}$ test tube. Bone marrow smears were then prepared from each rat. The number of MPCE in 1,000 polychromatic erythrocytes (PCE), which provides an index of chromosomal damage, was counted ${ }^{18)}$.

\section{Endocrine assays}

Two $\mathrm{ml}$ of blood was centrifuged and serum was isolated and stored at $-80^{\circ} \mathrm{C}$ until use. Levels of thyroid hormones ( $\mathrm{T}_{3}$ and $\mathrm{T}_{4}$ ), and cortisol (adrenocortical hormone) were measured using radioimmunoassay (RIA) kits purchased from Shanghai Institute of Chemical Agents (Shanghai, China) $)^{10)}$.

\section{Statistical analysis}

The analysis of variance (ANOVA), the Scheffe's test and Chi-square test were performed on analyses of the data obtained in this study using StatView Ver. 5.0 (SAS Institute Inc., USA, 1998). The probability less than 0.05 was considered to be significant.

\section{Results}

Concentrations of $\mathrm{BPb}$ and $\mathrm{BZn}$ in each group of rats were shown in Table 1. $\mathrm{BPb}$ in $\mathrm{Pb}$ group and $\mathrm{Pb}+\mathrm{Zn}$ group was significantly higher than that in controls or $\mathrm{Zn}$ group. In the $\mathrm{Pb}+\mathrm{Zn}$ group, $\mathrm{BZn}$ was significantly lower than in $\mathrm{Zn}$ group.
Percentages of MPCE were shown in Table 2. In Pb group and $\mathrm{Pb}+\mathrm{Zn}$ group, MPCE was significantly higher than that in controls, whereas there was no change in $\mathrm{Zn}$ group. Proportion of abnormal sperm in four groups of rats was shown in Table 3. In $\mathrm{Pb}$ group and $\mathrm{Pb}+\mathrm{Zn}$ group, Proportion of abnormal sperm was significantly higher than that in controls, however proportion of abnormal sperm in $\mathrm{Pb}+\mathrm{Zn}$ group was significantly lower than that in $\mathrm{Pb}$ group. There was no significant difference in proportion of abnormal sperm between $\mathrm{Zn}$ group and controls.

The levels of serum $T_{3}, T_{4}$ and cortisol in four groups of rats were shown in Table 4. In $\mathrm{Pb}$ group or $\mathrm{Pb}+\mathrm{Zn}$ group, serum $\mathrm{T}_{3}$ and $\mathrm{T}_{4}$ were significantly lower, and on the contrary, serum cortisol were significantly higher than those in controls. In addition, level of serum $\mathrm{T}_{4}$ in $\mathrm{Pb}+\mathrm{Zn}$ group was the lowest among the four groups. In $\mathrm{Zn}$ group, serum $\mathrm{T}_{3}$ was significantly lower than that in controls and whereas there were no significant differences in the serum $\mathrm{T}_{4}$ and cortisol compared with controls.

\section{Discussion}

Flora et al ${ }^{8)}$ reported a decrease in $\mathrm{BPb}$ level of rats during Zn co-administration. In the present study, there were no significant differences in concentrations of $\mathrm{BPb}$ between the groups that received $\mathrm{Pb}$ alone and that received both $\mathrm{Pb}$ and $\mathrm{Zn}$. No effects of $\mathrm{Zn}$ on $\mathrm{BPb}$ may be associated with 
Table 3. Effect of $\mathrm{Zn}$ on the proportion of abnormal sperm

\begin{tabular}{lcccccc}
\hline Groups & \multicolumn{2}{c}{ Treatment $(\mathrm{mg} / \mathrm{kg})$} & & $\begin{array}{c}\text { No. of } \\
\text { sperm }\end{array}$ & $\begin{array}{c}\text { No. of abnormal } \\
\text { sperm }\end{array}$ & $\begin{array}{c}\text { Proportion of abnormal } \\
\text { sperm }(\%)\end{array}$ \\
\cline { 2 - 3 } Co acetate & Zn acetate & & 7,000 & 54 & 7.7 \\
$\mathrm{Zn}$ & 0 & 0 & & 7,000 & 42 & 6.0 \\
$\mathrm{~Pb}$ & 0 & 4 & & 7,000 & 106 & $15.1^{\mathrm{a}, \mathrm{b}}$ \\
$\mathrm{Pb}+\mathrm{Zn}$ & 25 & 0 & & 7,000 & 78 & $11.1^{\mathrm{a}}$ \\
\hline
\end{tabular}

${ }^{\mathrm{a}} p<0.05$, compared with control group; ${ }^{\mathrm{b}} p<0.05$, compared with $\mathrm{Pb}+\mathrm{Zn}$ group by the $\chi^{2}$ test.

Table 4. Effects of $\mathrm{Zn}$ on the thyroid and adrenocortical functions

\begin{tabular}{|c|c|c|c|c|c|}
\hline \multirow[t]{2}{*}{ Groups } & \multicolumn{2}{|c|}{ Treatment (mg/kg) } & \multicolumn{2}{|c|}{ Levels of serum thyroid hormones } & \multirow{2}{*}{$\frac{\text { Level of serum cortisol }}{(\mathrm{nmol} / \mathrm{l})}$} \\
\hline & $\mathrm{Pb}$ acetate & $\mathrm{Zn}$ acetate & $\mathrm{T}_{3}(\mathrm{nmol} / \mathrm{l})$ & $\mathrm{T}_{4}(\mathrm{nmol} / \mathrm{l})$ & \\
\hline Controls & 0 & 0 & $1.54 \pm 0.59$ & $29.72 \pm 7.79$ & $7.54 \pm 3.7$ \\
\hline $\mathrm{Zn}$ & 0 & 4 & $0.91 \pm 0.40^{\mathrm{a}}$ & $25.80 \pm 6.22$ & $10.82 \pm 4.9$ \\
\hline $\mathrm{Pb}$ & 25 & 0 & $0.47 \pm 0.12^{\mathrm{b}}$ & $21.20 \pm 10.02^{\mathrm{a}}$ & $14.92 \pm 5.7^{\mathrm{a}}$ \\
\hline $\mathrm{Pb}+\mathrm{Zn}$ & 25 & 4 & $0.42 \pm 0.12^{\mathrm{b}}$ & $18.43 \pm 7.14^{\mathrm{b}}$ & $13.34 \pm 2.3^{\mathrm{a}}$ \\
\hline
\end{tabular}

${ }^{\mathrm{a}} p<0.05$ and ${ }^{\mathrm{b}} p<0.01$, compared with control group by the Scheffe's test.

the facts that the dose of $\mathrm{Zn}$ was considerably lower than that of $\mathrm{Pb}$. On the contrary, the concentration of $\mathrm{BZn}$ in the group given $\mathrm{Zn}$ alone was significantly higher than that in the $\mathrm{Pb}+\mathrm{Zn}$ group. It suggests that $\mathrm{Pb}$ decreased the concentration of $\mathrm{BZn}$ when both $\mathrm{Pb}$ and $\mathrm{Zn}$ were administered intraperitoneally. It has been recognized that $\mathrm{Zn}$ cannot cross biological membranes by simple diffusion and need a trafficking system for its cellular uptake and release ${ }^{19)}$. Putative mammalian zinc transporters have now been cloned ${ }^{20)}$. Because divalent $\mathrm{Pb}$ and $\mathrm{Zn}$ potentially have similar chemical characteristics, it may be possible that $\mathrm{Pb}$ influences absorption or distribution of $\mathrm{Zn}$ in blood or other tissues through interfering the trafficking system of $\mathrm{Zn}$.

Tachi et al..${ }^{21)}$ reported that $\mathrm{Pb}$ caused a significant increase in the frequency of chromosomal aberrations and micronuclei in rat bone marrow cells. In the present study, an increased frequency of MPCEs was observed in the groups given $\mathrm{Pb}$ alone and both $\mathrm{Pb}$ and $\mathrm{Zn}$. It suggests that $\mathrm{Pb}$ increased frequency of MPCEs and that $\mathrm{Zn}$ did not prevent the genotoxic effect of $\mathrm{Pb}$.

The proportion of abnormal sperm was significantly higher in the groups given $\mathrm{Pb}$ alone or $\mathrm{Pb}+\mathrm{Zn}$ group than that in controls. An increase in the proportion of abnormal sperm in the group given both $\mathrm{Pb}$ and $\mathrm{Zn}$ was less than that in the group given $\mathrm{Pb}$ alone. These data suggested that $\mathrm{Pb}$ increased abnormal sperm and $\mathrm{Zn}$ could decrease it. This agrees with the observation by Batra et al. ${ }^{19,22)}$. That the toxic effects of $\mathrm{Pb}$ on male reproductive system could be ameliorated by
$\mathrm{Zn}$ supplementation. As evidence has shown that $\mathrm{Zn}$ exists in spermatozoa within the seminiferous tubules and helps spermatogenesis ${ }^{19,23)}, \mathrm{Pb}$ may result in disruption of the metabolic functions of enzymes containing $\mathrm{Zn}$, inducing testicular damage. Batra et al. ${ }^{9)}$ reported that there was a $30 \%$ reduction in $\mathrm{Pb}$ deposition in the testes when $\mathrm{Zn}$ was coadministered. The protective effect of $\mathrm{Zn}$ on reproductive toxicity of $\mathrm{Pb}$ may be attributed to competition between $\mathrm{Pb}$ and $\mathrm{Zn}$, or reduction of available $\mathrm{Pb}$-binding sites in the testicular tissue.

Many researchers have studied roles of $\mathrm{Zn}$ in the prevention and treatment of toxic effects of $\mathrm{Pb}$. Thyroid gland is a toxic target organ of $\mathrm{Pb}$, however, reports on the interactions of $\mathrm{Zn}$ in $\mathrm{Pb}$ toxicities in thyroid gland are rare. In this study, serum $T_{3}$ and $T_{4}$ were significantly lower in the groups given $\mathrm{Pb}$ alone or both $\mathrm{Pb}$ and $\mathrm{Zn}$ than those in control. Especially, $\mathrm{T}_{4}$ in the group given both $\mathrm{Pb}$ and $\mathrm{Zn}$ was decreased most obviously among the 4 groups. Alterations in circulating levels of $\mathrm{T}_{3}$ and $\mathrm{T}_{4}$ in $\mathrm{Pb}$-exposed workers, experimental animals, and fishes have been reported ${ }^{24-26)}$, as confirmed by decrease in serum $T_{3}$ and $T_{4}$ in the present study. This may be associated with the fact that $\mathrm{Pb}$ inhibits synthesis and release of thyroid hormone at the glandular level through affecting thyroid iodine uptake or TSH release from pituitary or TRH release from hypothalamus ${ }^{25,27,28)}$. As excessive amount of $\mathrm{Zn}$ decreases thyroid hormone levels ${ }^{29,30)}$, a greater decrease in serum $\mathrm{T}_{4}$ in the group received both $\mathrm{Pb}$ and $\mathrm{Zn}$ seems to be a consequence of the joint toxic action of $\mathrm{Pb}$ 
and $\mathrm{Zn}$. Hereafter, it is necessary to investigate effect of $\mathrm{Zn}$ with low dosage on $\mathrm{Pb}$ toxicity to thyroid function. Vyskocil et al. ${ }^{31)}$ found that $\mathrm{Pb}$ increases serum corticosterone level in rats. In the present study, the increased serum cortisol as another adrenal corticoid hormone was observed in groups that received $\mathrm{Pb}$ alone or both $\mathrm{Pb}$ and $\mathrm{Zn}$, and $\mathrm{Zn}$ did not prevent such an increase in serum cortisol. Mechanisms underlying the effects of $\mathrm{Pb}$ on corticosterone and cortisol levels should be investigated further.

The present study suggested that $\mathrm{Zn}$ exerted a protection against toxic effects of $\mathrm{Pb}$ on male reproductive system, while it could enhance the toxic effects of $\mathrm{Pb}$ on thyroid function. On the other hand, $\mathrm{Zn}$ might have not affect the toxicities of $\mathrm{Pb}$ on cytogenetic systems as indicated by MPCE frequencies or serum cortisol levels under the dosing of the present study. It indicates that the effects of $\mathrm{Zn}$ on $\mathrm{Pb}$ toxicities should be evaluated systematically and $\mathrm{Zn}$ should not be used for treatment of the patients exposed to $\mathrm{Pb}$ unconditionally. Meanwhile, it is also necessary to explore further the effects of $\mathrm{Zn}$ on toxicities of $\mathrm{Pb}$ with low dose exposure.

\section{References}

1) Basha MR, Wei W, Brydie M, Razmiafshari M, Zawia NH (2003) Lead-induced developmental perturbations in hippocampal Spl DNA-binding are prevented by zinc supplementation: in vivo evidence for $\mathrm{Pb}$ and $\mathrm{Zn}$ competition. Int J Devl Neuroscience 21, 1-12.

2) Cerklewsk FL, Forbes RM (1976) Influence of dietary zinc on lead toxicity in the rat. J Nutr 106, 689-96.

3) Agnieszka SC, Anna S, Maria S, Teresa K, Renata S, Roman P, Dariusz A, Jozef F, Martyna KS (2000) The inhibitory effect of zinc on cadmium-induced cell apoptosis and reactive oxygen species (ROS) production in cell cultures. Toxicology 145, 159-71.

4) Afonne OJ, Orisakwe OE, Ndubuka GI, Akumka DD, Ilondu $\mathrm{N}$ (2000) Zinc protection of mercury induced hepatic toxicity in mice. Biol Pharm Bull 23, 305-8.

5) Walsh CT, Sanstead HH, Prasad AS, Newberne PM, Fraker PJ (1994) Zinc: health effects and research priorities for the 1990s. Environ Health Perspect 102, 5-46.

6) Brzóska MM, Moniuszko-Jakoniuk J, Jurczuk M, GałazynSidorczuk M (2002) Cadmium turnover and changes of zinc and copper body status of rats continuously exposed to cadmium and ethanol. Alcohol Alcoholism 37, 213-21.

7) Hasan MZ, Seth TD (1981) Effect of lead and zinc administration on liver, kidney and brain levels of copper, lead, manganese and zinc and on erythrocyte ALA-D activity in rats. Toxicol Lett 7, 353-8.

8) Flora SJ, Jain VK, Behari JR, Tandon SK (1982) Protective role of trace metal in lead intoxication. Toxicol Lett 13, 51-6.
9) Batra N, Nehru B, Bansal MP (1998) The effect of zinc supplementation on the effects of lead on the rat testies. Reprod Toxicol 12, 535-40.

10) Piao F, Wan B, Zhu W (1991) Effects of lead on thyroid function and morphology in pregnant rats. Chinese J Ind Hgy And Occup Dise 9, 210-5.

11) Hsu PC, Hsu CC, Liu MY, Chen LY, Guo YL (1998) Leadinduced changes in spermatozoa function and metabolism. J Toxico Environ Health A 55, 45-64.

12) Bay BH, Wang MC, Yip GM (1998) Effect of intraperitoneal administration of zinc on C57/6J mouse liver-alight microscopic study. Okajimas Folia Anat Jpn 74, 279-91.

13) Rehman SU, Din KU, Hasan M, Chandra O (1982) Zinc, copper and lead levels in blood, spinal cord and different parts of the brain in rabbit: effect of zinc-intoxication. Neurotoxicology 3, 195-203.

14) Satija NK, Vij AG (1995) Preventive action of zinc against lead toxicity. Indian J Physiol Pharmacol 39, 377-82.

15) Claverie C, Corbella R, Martin D, Diaz C (2000) Protective effects of zinc on cadmium toxicity in rodents. Biol Trace Element Res 75, 1-9.

16) Tandon SK, Singh S, Prasad S, Mathur N (1997) Influence of L-lysine and zinc administration during exposure to lead or lead and ethanol in rats. Biol Trace Element Res 57, 51-8.

17) Wadi SA, Ahmad G (1999) Effects of lead on the male reproductive system in mice. J Toxicol Environ Health 56, 513-21.

18) Schmidt W (1975) The micronucleus test. Mutat Res 31, 9-15.

19) Mcmahon RJ, Cousins RJ (1998) Regulation of the zinc transporter ZnT-1 by dietary zinc. Proc Natl Acad Sci USA 95, 4841-6.

20) Kelleher SL, Lonnerdal B (2002) Zinc transporters in the rat mammary gland respond to marginal zinc and vitamin $\mathrm{A}$ intakes during lactation. J Nutr 132, 3280-5.

21) Tachi K, Nishimae S, Saito K (1985) Cytogenetic effects of lead acetate on rat bone marrow cells. Arch Environ Health 40, 144-7.

22) Batra N, Nehru B, Bansal MP (2001) Influence of lead and zinc on rat male reproduction at 'biochemical and histopathological levels'. J Appl Toxicol 21, 507-12.

23) Orisakwe OE, Afonne OJ, Nwobodo E, Asomugha L, Dioke CE (2001) Low-dose mercury induces testicular damage protected by zinc in mice. Eur J Obstet Reprod Biol 95, 92-6.

24) Hariguchi $S$ (1987) Measurement of total triipdothyronine $\left(\mathrm{T}_{3}\right)$, total thyroxine $\left(\mathrm{T}_{4}\right)$ and thyroid-stimulating hormone in lead exposed workers. Osaka City Med 33, 51-6.

25) Singh B, Dhawan D (1999) Effect of lithium on thyroid ${ }^{131}$ iodine uptake, its clearance, and circulating levels of triiodothyronine and thyroxine in lead-treated rats. Rodiat Environ Biophys 38, 261-6.

26) Chaurasia SS, Gupta P, Kar A, Maiti PK (1996) lead induced thyroid dysfunction and lipid peroxidation in the fish clarias batrachus with special reference to hepatic type 1-5'- 
monodeiodinase activity. Bull Environ Contam Toxicol 56, 649-54.

27) Kitti SR, Sathyanesan AG (1987) Lead nitrate induced changes in the thyroid physiology of the catfish Clarias batrachus (L). Ecotoxicol Environ Safety 13, 1-6.

28) Huseman CA, Moriarty CM, Angle CR (1987) Childhood lead toxicity and impaired release of thyroid stimulating hormone. Environ Res 42, 524-33.

29) Sohair AM (2001) Effect of glutathione (GSH) depletion on the serum levels of triiodothyronine $\left(\mathrm{T}_{3}\right)$, thyroxine $\left(\mathrm{T}_{4}\right)$, and
$\mathrm{T}_{3} / \mathrm{T}_{4}$ ratio in allyl alcohol-treated rats and possible protection with zinc. Intern J Toxicol 20, 15-20.

30) Kaya S, Kecec T, Haliloglu S (2001) Effects of zinc and vitamin A supplements on plasma levels of thyroid hormones, cholesterol, glucose and egg yolk cholesterol of laying hens. Res Vet Sci 71, 135-9.

31) Vyskocil A, Fiala Z, Ettlerova E, Tenjnorova I (1990) Influence of chronic lead exposure on hormone levels in developing rats. J Appl Toxicol 10, 301-2. 